Małgorzata Grącik-Zajaczkowski

\title{
FROM EU-CENTRIC APPROACH TO MULTILEVEL GOVERNANCE: IS IT ONLY THE EU THAT HOLDS THE CARDS IN THE REGION? THE ROLE OF INTERNATIONAL ORGANIZATIONS AND GROUPINGS IN SHAPING THE DYNAMICS OF PROCESS INHERENT IN THE REGION ${ }^{2}$
}

Keywords: Central and Eastern European Countries, security and defense policy, European Union, NATO, OSCE.

ABSTRACT: This article focuses on the Central and Eastern European in the process of shaping their security relations. The aim of the paper is to present and analyze the evolution of security relations in the region under the aegis of the EU, NATO and the Organization for Security and Co-operation in Europe (OSCE). The interplay of the institutions shows that the EU is not a single power in the European security system thus the maintenance of stable and peaceful relations depend mostly on cooperation between a number of institutions and groupings. The EU and NATO's role was central due to their policies of enlargement and the stabilization effects on third partner countries. The OSCE with its well promising position in Europe has been weaken due to decline of interests of major power states and its functions performed simultaneously by the EU and NATO. Both organizations have taken to a large extent the place of the OSCE.

1 Małgorzata Grącik-Zajaczkowski, Warsaw School of Economics, Institute of International Security, mgraci@sgh.waw.pl.

2 This research project has benefited from funding under the Polish "National Science Centre" (NCN) grant titled "European Neighbourhood Policy: (multi-level) governance, the reform process and the prospect of enhanced cooperation in the region", OPUS/ HS5, No. 2013/09/B/HS5/04534. 


\section{INTRODUCTION}

The European Union (EU) is a supranational institution which is shaping dynamics of different processes in the regions and beyond. However the EU cannot exert its power on its own since its functioning and bargaining position rely on other institutions and state-actors. It is particularly relevant in security and defense areas and in relation to the Central and Eastern European countries (CEECs). In this respect the approach of multi-level governance (MLG) can be an useful mean to explain the situation in which a variety of authoritative institutions at supranational, national and subnational levels are coming to an agreement. Under the perspective central governments remain vitally important, but they do not have a monopoly of decision-making power. Instead, policy-making responsibility is being shared among a variety of actors functioning at supranational, national or regional level. Moreover the approach of MLG can be extended to other international arena beyond the exclusive EU's sphere. It may be applied to Euro-Atlantic system as a whole based on different institutions and organizations, where the EU is exerting its influence as one of many institutional actors.

For the purpose of explaining the problem raised in the title there were taken sharp and specific selection. Firstly, on the grounds of tight relations with the EU there were chosen Central and Eastern European countries (CEECs) in the process of shaping their security relations. Second, the subject area for the analysis is security and defense issue since the EU does not have explicit advantage in that filed against economic or social spheres. Third, security has remained the most vital interest for the CEECs as their geopolitical conditions require specific arrangements and bargaining. Therefore the aim of the paper is to present and analyze the evolution of security relations in the region under the aegis of the EU, NATO and the Organization for Security and Co-operation in Europe (OSCE). The interplay of the institutions shows that the $\mathrm{EU}$ is not a single power in the European security system thus the maintenance of stable and peaceful relations depend mostly on cooperation between a number of institutions and groupings. Although the security picture involving the EU, NATO and the OSCE seems to be much simplified (many actors and groupings 
are excluded) it depicts general role and importance of the EU in the context of European security.

\section{INTERLOCKING INSTITUTIONS}

By the end of the cold war Euro-Atlantic organizations have faced two major challenges: first - internal reform of their structures and functions, second, adaptation to changing international relations. The latter meant recognition of a new kind of challenges and threats and proper response to security and economic risks. The Western institutions were expected to provide solid foundations for stability and prosperity in Europe, particularly in opinion of CEECs. Faced with the collapse of the previous system, these countries were forced to adapt to new conditions and build new relationships. Therefore the Euro-Atlantic institutions were to fill the 'security gap' which has arisen after the dissolution of the Eastern blocs.

Each of the Euro-Atlantic institutions have played substantial role in building new relations in Europe after the breakthrough of 1989. The expansion of the EU and NATO and the institutionalization of the OSCE in the early 1990 have resulted in a complex web of overlapping institutions. It stems from, first, common coverage of issue and second overlapping membership (Chart 1). In this respect the concept of 'division of labor' seemed to be relevant as it indicated harmonious cooperation of the institutions in different security areas. According to it the NATO would deal with military aspects, the EU would tackle politico-economic issues and the OSCE would focus on social and humanitarian matters (Rotfeld,, 2000, p.99).

The expansion of the EU and the NATO to the Eastern Europe have been driven by two factors - policy of enlargement and promotion of democracy. Both institutions have assumed almost the same criteria for attracting partner countries, the perspective of membership and the promotion of democratic values, rule of law and human rights. It was clear that only the incentives coming from the EU's and NATO's would offset domestic economic and political costs resulted from systemic transformation. Thus only a membership perspective in the EU and NATO had the 
potential to put a pressure to the CEECs to continue their political changes and socio-economic reforms.

Since the decision on engagement was taken the question concerned the issue of which institution - the EU or the NATO - would open its 'door' first? The EU membership has given a guarantee of an access to European internal market, the EU's subsidies of agriculture and regional policies. The inclusion into the NATO's structure has offered in turn military protection of the alliance and the participation in the decision- making procedure of the most powerful military organization (Schimmelfennig, 2007, p.129). It seemed that the EU and the NATO have been complementary to each other, and no serious tensions took place. In practice, their mutual relations have undergone grave strains, particularly concerning the concept of building European security and defense policy (CSDP) and European military capabilities (Grącik, 2002, pp. 65-70; Grącik, 2003, pp. 115-125).

Accession to the EU and NATO was expected to undercut resources, budgets and decision-making procedures of both organizations - the EU and NATO. The expansion and the final decision on enlargement depended on attitude of their member states towards extension of the economic, political and security zone to the CEECs. The Western attitude towards the interest and aspirations of the CEESs was changing which in consequence resulted in enlargement. However it took several years to overcome the reluctance and restraint in European political circles. It was until 1993 and 1994 respectively that the EU and the NATO members decided to initiate the process of the "open door" policy. It directly touched not only the CEECs candidate countries but also affected the partner countries from the region and beyond (i.e. Russia) (Schimmelfennig, 2007, pp.128-129).

\section{THE OSCE}

The OSCE is a world's largest regional organization which is specialized in early warning, conflict prevention, crisis management and 
post-conflict rehabilitation in Europe and Euro-Asian region. It is an institutional forum for building security cooperation between its 57 member states and 11 partner countries from North America, Europe, Russia, Central Asia and Caucasus. The OSCE (former Conference on Security and Cooperation in Europe, CSCE) had played crucial role in the cold war period through creating multilateral forum for dialogue and negotiation between the rivals form the West and the East. It commenced a dialogue on human rights issues which constituted a breach in mutual relations between the cold war adversaries. At the beginning of 1990 the organization has set a new course. It was called upon to play a new role in Euro - and Asian regions by focusing on creating a new order of security and cooperation in Europe based on the concept of cooperative security.

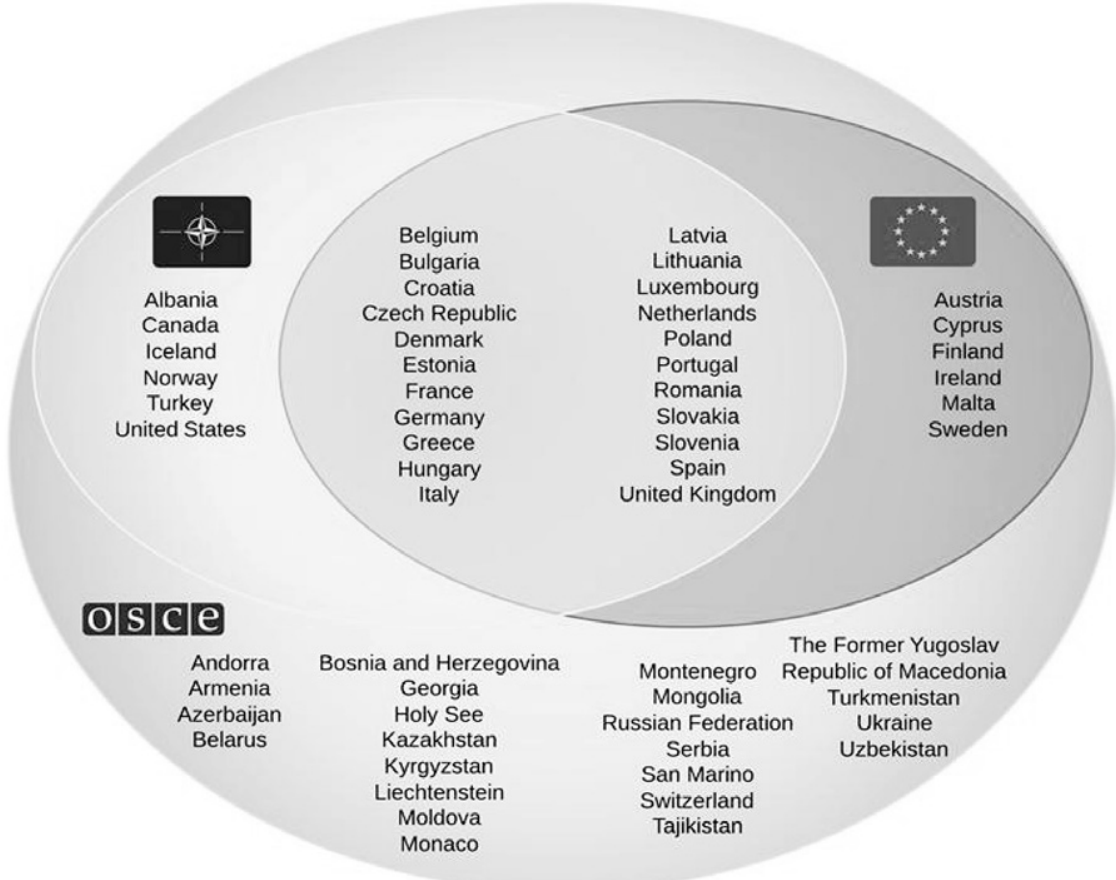

Chart 1.

Source: https://melissaguinan.wordpress.com/research/. 
In the early 1990 the OSCE was seeking to establish a broad web of cooperation with different international organizations. The institution could work effectively only with substantial support of its members or other international organizations. It managed to establish a cooperation framework with the Council of Europe, the G-7, OECD, the ECE and the EBRD. However, the strongest contacts were built with the EU and the NATO, which resulted in bringing closer their functions and objectives. On the other hand, similar objectives and overlapping membership ran the risk of doubling their functions and activities which led to increasing competition and rivalry between the institutions.

However over the years the expected "division of labor" between the OSCE, the EU and NATO has transformed into the state of "inter-blocking organizations" with similar functions and tasks (Rotfeld, 2000, p. 100). It was in particular the EU and NATO which have been tending to embrace more purposes and tasks. In fact all three organizations have been seeking new role for themselves in new international circumstances though the EU and NATO have enjoyed greater support and assistance from their members than the OSCE. In the 1990 the OSCE expended its work in the areas of early warning, conflict prevention, conflict management and post-conflict rehabilitation, while previously since in the 1970 it had been engaged in arms control, disarmament and non-proliferation efforts. Its fragile support from member states stems from their divergent interests and conflicting visions related to European security and beyond.

In the Euro-Atlantic institutional triangle of the EU, NATO and OSCE, the latter has occupied the weaker position despite its substantial contribution to European stability at the end of the cold war. The participation of the OSCE in the process of building European security was less noticeable than the NATO's crisis management operations or EU's economic assistance. The OSCE well promising position in Europe in the early 1990 was broken because other institutions (i.e. the EU and NATO or the UN) and some member state (i.e. Russia) have started to take over its functions in the area of actions restricted to the OSCE. Other organizations have gradually seized the realm occupied by the OSCE and developed their capabilities in the fields where the OSCE had been active for a long time ago (Biscop, 2005). The EU has grown up alongside the NATO as a lead- 
ing actor in area of peace-building and security while the OSCE presence has been often neglected and overlooked. Traditional geographical areas of OSCE activity such as Balkans or Eastern Europe were almost fully intercepted by the EU. Moreover, Russia has return as a key player in the region and it started to put its own terms. Central Asia, the Caucasus and the South Eastern Europe have again found themselves in the orbit of particular interests of Russia.

The real test for the OSCE was the engagement during the military conflict in the Balkans, especially in Kosovo. Under the auspices of the OSCE there was established in 1999 the Kosovo Verification Mission, which was the largest OSCE field operation. Its aim was to monitor, investigate and collect cases of human rights violations committed in the conflict but also support the work of local institutions. Over the years it turned out that the OSCE could play an active and important role in the crisis only with strong support of the key power states and the EuroAtlantic security institutions. It meant that the OSCE operational mandate depended on the contribution and interest of their influential members, namely Western European states, the US and Russia.

\section{THE EU}

In the early 1990 Europe found itself in a new security circumstances. The changing strategic landscape, after the 1989 events in CEECs compelled the European Community members and the US to establish new kinds of relations with former adversaries. The cold war concern about instability in the partitioned Germany and divided continent was supplemented by anxieties over potential instability centered in the Central and Eastern part of the Old Continent. Nevertheless, these profound political and economical changes in the CEECs did not mean that all existing divisions and obstacles between the two former political and military blocks had suddenly disappeared. The collapse of the communist bloc created new international circumstances in which integrating Western European countries and the new emerging democracies had to find their proper place and role. 
One of the biggest challenge for the Western European countries was the establishment of new political and economic relations with CEECs, which were seeking any closer integration with the Community. The breakdown of the bipolar East-West order created a situation in which the only powerful and attractive pole for CEECs was the West. The main pressure for the integration derived from the Euro-Atlantic institutions which were the only authority to push the CEECs into the systemic reforms. The opinion that Moscow would try to influence situation in these countries and regain its lost power in the region had a powerful effect on the CEECs towards their faster and deeper integration with the West. Poland and the remaining states from Central Europe proclaimed, from the very beginning, that their economic and political transitions were based principally on cooperation with Western security structures. The new European democracies counted on exploring contacts with NATO, the Western European Union (WEU) and the European Communities, simultaneously striving for the breakup of the Warsaw Pact.

The CEECs sought to be situated in the Pan-European system of collective security, involving the United States and Western European countries. The only reliable security guarantees they saw was NATO supplemented by security and defense arrangements developed within the EU framework with an active participation of the WEU (Parzymies, 1997, p.79). After the dissolution of the Warsaw Pact (1 July 1991) the CEECs found themselves in a so-called "gray sphere" which forced them to seek other institutional forms of cooperation which would guarantee them some scope of security. Therefore, they started to commence co-operation with NATO, the European Communities and the WEU with the aim of gaining security guarantees in the case of a threat from the former Soviet Union.

The first that responded to the CEECs' endeavors was the WEU. In the 1990 the organization was responsible for shaping security and defense policy of the members of European Community. Regarding the position of Poland, Hungary and the Czech Republic, which gained the status of states associated with the European Communities, the WEU decided to upgrade mutual cooperation in 1994. In the "Kirchberg Declaration" it adopted new arrangements aimed at strengthening relations with nine CEECs. A new status of "association with the WEU" was established for 
Poland, Hungary, the Czech Republic, Bulgaria, Estonia, Lithuania, Latvia, Slovakia and Romania (WEU, 2000, p. 17).

Despite the fact that the Kirchenberg declaration was not synonymous with security guarantees for CEECs, it justified significant progress in cooperation on security matters between the Western and Eastern countries. The status of "associate partners" of the WEU entitled the states to be involved in the following WEU activities: meetings of the WEU Council; liaison arrangements with the Planning Cell; participation in common exercises and joining in the WEU-led military operations. The operations under the WEUs command were established as "Petersberg tasks" and embraced the humanitarian missions, rescue operations, peacekeeping and peacemaking operations (WEU, 2000, p. 11). Petersberg missions were considered as a new instrument at the WEU's disposal, set up with the aim of building crisis management capabilities of the organization in the case of occurring international crisis situations. At the Lisbon meeting in March 1995, the WEU Council of Ministers discussed a proposal referring to the practical cooperation with "associate partners" in the framework of the Petersberg tasks. The WEU members wanted to involve associated partners in the development of their operational activities; including peacekeeping efforts and humanitarian actions. They emphasized also a need to develop cooperation between "associated partners of the WEU" and NATO.

The approach of strengthening institutional cooperation between the CEECs, the WEU and the NATO has become a dominant objective in terms of building European security coherence and stability. The goal of including the CEECs in the process of forming European security architecture was a meaningful signal, especially in the situation of shaping the European crisis management capabilities. The new status of CEECs as "associate partners" of the WEU and "associated to the European Communities" changed their situation in Europe considerably. The frontrunners from Central and Eastern Europe gained hope for becoming members in Western institutions and entering broader cooperation with the North Atlantic Alliance.

At the end of 1991, Poland, the Czech Republic, Hungary and Slovakia managed to conclude their association agreements with the European 
Community; which helped to broaden their collaboration with WEU. The states from the so-called "Luxembourg group" (the Czech Republic, Hungary and Poland) signed the Europe Agreement in December 1991 and made the goal of membership in the EU their strategic objective.

The enthusiasm of the CEECs towards the integration into the EuroAtlantic structure was opposite to the approach represented by the Western European countries. Central and Eastern Europe appeared for them as a potentially unstable area, prone to evoking conflicts and providing tensions. The region was perceived as the "gray zone", which was likely to cause threats to European security (Zięba, 1999, p. 59-62). This resulted from the fact that Poland and other countries from the former Eastern bloc had to cope with their communist legacy which were associated with economic difficulties, crises of public finances and social tensions. The formation of new political and social systems combined with the lack of suitable neighboring agreements, bore some misgivings within the Western states. They pointed out unsettled situations that referred to ethnic, religious and national minority groups, which could cause tensions and lead to open conflicts in CEE (Kuźniar, 2001, p. 61)

At the beginning of the transformation process, Western Europeans claimed that fast integration of CEECs could create an unstable area in which the most dangerous threat arising from the renewal of nationalterritorial antagonisms. They reiterated that the process of transition would have serious consequences for West European countries, resulting in mass migration, organized crime and trafficking. Another premise related to the phenomenon of "spreading instability" by the CEECs was "concern for the security interests of the Soviet Union and a suggestion to look upon Central Europe as a special buffer zone between the West and the zone of Russian interests" (Kuźniar, 2001, p. 27). This kind of statement was shared by majority of EU member states and led to the initiative that aimed at guaranteeing stability in Europe through setting up bilateral agreements on good neighborliness.

In consequence the CEECs aspirations in security and defense have been met by NATO. It was particularly important in situation where the WEU tasks and institutions were transferred into the EU under the framework of its European Security and Defense Policy (ESDP). The process of 
gradual incorporation of the WEU's political work had been accomplished at the end of 1999 and the organization ceased to exist in June 2011 (Bailes, Messervy-Whiting,, 2011, p.3).

\section{NATO}

After years of diplomatic endeavors taken by the most advanced neighbors from Central and Eastern Europe (i.e. the Czech Republic, Hungary and Poland) the objective of NATO enlargement to the East seemed to become a realistic achievement. However, the process of NATOs "open door policy" turned out to be feasible only in 1995, after the announcement of the document entitled "Study on NATO Enlargement". The CEECs' journey to enter the NATO started at the beginning of the 1990s, when national governments proclaimed their first declarations on joining the alliance. Poland and the remaining states from the Visegrad Group (the Czech Republic, Hungary and Slovakia) were the first counties from the former communist bloc which have outset systematic dialogue with NATO. The new situation between the CEECs and NATO members reflected the London Declaration of July 1990, which adopted the decision for establishment of a closer relationship with the former adversaries. The Document suggested "military contacts" between NATO and the Warsaw Pact members, regular diplomatic contacts and signing of a joint declaration by the nations of NATO and the former Warsaw Pact (North Atlantic Council, 1990).

According to mutual arrangements the NATO has set up the North Atlantic Cooperation Council (NACC) which was to serve as an inward body for strengthening and deepening co-operation between the NATO members and the former Warsaw Pact. The initial meeting of the NACC was held on 20 December 1991. This new institution absorbed all willing members of the OSCE and gave them hope for fast approaching the NATO structures. However the CEEC's visions of a fast-track enlargement of NATO encountered serious obstacles among NATO members who were reluctant to embrace the Eastern neighbors with military guarantees of the Alliance. Therefore an answer to the intensifying campaign in favor 
of joining the NATO, it was an initiative known as the "Partnership for Peace" (PfP). Formally, the program of PfP was announced at the NATO Summit in Brussels in January 1994.

Following the Brussels arrangements NATO addressed an invitation for each country participating in NACC as well as to the OSCE members to adopt an individual program within the framework of PfP. The program was perceived by Western countries as an instrument for cooperation in security matters between them and the CEECs. It was to promote and strengthen further transformation of the CEEC's economies. Furthermore, the PfP program was established with the goal of intensifying cooperation with NACC members to be able to meet requirements for future international peacekeeping operations under the NATO's command. The key objective of the program was to launch consultations with CEECs on any security issues in which the states were interested. The main task was the establishment of procedures for the democratic control of army forces while introducing transparency in defense planning and budgeting.

Contrary to the viewpoints of NATO members, the CEECs expressed their disappointment with the announcement of the PfP program. Although the PfP did not bring any security guarantees for CEECs the prospect of early accession to the Alliance was very vague. Poland and other counties form Central Europe sustained strong reservation towards the program and even proposed its refusal (Zięba, 1999, pp. 126-127). In the Polish authorities' opinion the loosely connected cooperation within the framework of PfP did not give any certainty for an invitation to NATO accession. In Poland and the Czech Republic there arouse some sort of impression that the membership of NATO was imminent and that PfP program was an activity aimed at shelving the CEECs' accession to the Alliance.

Despite this fact that the PfP program did not match Poland's, and other CEECs' aspirations, they decided to participate in the project and became active members. Participation in the PfP program was a vital and necessary factor which was taken into account during the decision on the NATO's enlargement. Therefore taking part in PfP activities became a necessary condition for the CEECs to be invited to the NATO accession talks. Finally, the expectations of the CEECs were met in 1995 with the 
adoption of the document entitled "Study on NATO Enlargement" (28 September 1995). The "Study" embraced the broad range of objectives and tasks that the accession countries were facing. The candidates were obliged to fulfill all recommended political and military conditions mainly through their active participation in the PfP program and the NACC. To enhance and strengthen cooperation within the framework of the NACC, the Alliance decided (on 30 May 1997 in Sintra, Portugal) to replace the former institution with another one, called Euro-Atlantic Partnership Council (EAPC).

The NATO's enlargement was strongly supported by the US administration, which considered the process as a good incentive for maintaining the process of political and economic transformation in CEECs. Engaging these countries in the accession to NATO created an area of stability and of balanced relationships, setting up security in case of a possible spread of unrest from this region to Western European states (Holbrooke, 1995). The protracted delay in decisions on the NATO's enlargement was partly caused by the position of Russia, which took up a decisive campaign against the operation. During Russian-NATO talks, which were conducted on the occasion of establishing the mutual "Founding Act", the problem of NATO's enlargement was broadly discussed. The Russian authorities claimed that they should have had "veto" powers over NATO's security arrangements threatened the risk of provoking nationalist reactions. Moscow had perceived NATO as a traditional military pact that would strive for expansion into CEECs and push out Russia from the European region.

As a counterbalance to the Euro-Atlantic proposal, Russia declared a building of a Pan-European security system based on the conception aimed at strengthening the OSCE. Ultimately the decision on launching the NATO's enlargement was adopted at the summit in Madrid on 9 July 1997, where the Czech Republic, Poland and Hungary were invited to begin accession talks. At the same time NATO reaffirmed that the alliance remained open to new members in conformity with article 10 of the Washington Treaty. On 12 March 1999 the three countries formally joined the alliance, bringing the number of member countries to 19 . On the $50^{\text {th }}$ anniversary of the establishment of the Washington Treaty held on 23-25 
April 1999 in Washington, the Czech Republic, Poland and Hungary were officially welcome to the circle of the Atlantic Alliance's members. Nevertheless, this significant event did not finish the process of adjustment of the new member states into the integrated alliance structure. NATO declared to be keeping its door open, which revealed in further accession of countries from former Eastern bloc. Relevant decision was undertaken at the NATO summit in Prague (21 November 2002), which led to invite Bulgaria, Estonia, Lithuania, Latvia, Romania, Slovakia, and Slovenia to accede the organization. All seven countries achieved their membership on 29 March 2004 and the number of all NATO members increased to 26. The latest enlargement took place in 2009. The accession process was completed for Albania and Croatia.

\section{CONCLUSIONS}

After the downfall of the communist bloc the EU and the NATO became the major institutions that started exerting their influence in CEECs. No other international organizations managed to play such an important and powerful role in the region. In the 1990 it was also the OSCE that contributed to the process of building security and stability in Europe and neighboring regions. However the EU and NATO were the key institutions which have prevailed on the Euro-Atlantic field and set directions of political and economic changes. The aim was to show the root causes of their involvement in the CEECs. The problem of role of international organizations in shaping the dynamics of process inherent in the region was related to the interplay between the EU, the NATO and OSCE.

The interplay between the organizations in the 1990 shows the process of building European cooperation in security issues between the Western democracies and the CEECs. The EU and NATO's role was central due to their policies of enlargement and the stabilization effects on third partner countries. The OSCE with its well promising position in Europe has been weaken due to decline of interests of major power states and its functions performed simultaneously by the EU and NATO. Both organi- 
zations have taken to a large extent the place of the OSCE. This was due to the process of transformation and adaptation to post cold-was circumstances which at the same time resulted in rising the role of the EU in security issues with essential support from the NATO.

\section{BIBLIOGRAPHY:}

Bailes, A., Messervy-Whiting, G.(2011). Death of an Institution: The End of the Western European Union, a Future for Europeam Defense? Egmont Paper, 46, Royal Institute for International Relations, Brussels.

Biscop, S. (2005). The EU, the OSCE and the European Security Architecture: Network or Labyrinth?, Vienna. Downloaded from: http://www.egmontinstitute.be/publication_article/the-eu-the-osce-and-the-european-security-architecture-network-orlabyrinth/.

Grącik, M. (2002). Development of international relations in the era of globalization. A wide perception of security, w: National culture - globalization - Roots and Wings, Sopron: University of West Hungary.

Grącik, M. (2003). The European Security - New threats and challenges after September $11^{\text {th }}$ 2001. Economic Papers, 35, pp. 115-125.

Holbrooke, R. (1995). America, a Europe Power. Foreign Affairs, 74 (2) (March/April 1995), pp. 38-50.

Kuźniar, R. (2001). Polityka bezpieczeństwa w polskiej polityce zagranicznej. In: R. Kuźniar (ed.). Polska polityka bezpieczeństwa 1989-2000 (pp. 91-121). Warszawa: Scholar.

North Atlantic Council. (1990). London Declaration, July 5-6.

Parzymies, S. (1997). Unia Europejska a Europa Środkowa. Polityczne aspekty współpracy. Sprawy Międzynarodowe, 50 (1).

Rotfeld, A.D. (2000). The OSCE Role in Cooperation with NATO and the EU in Southeastern Europe, July-December 2000. Croatian International Relations Review, 32 (7).

Schimmelfennig, F. (2007). European Regional Organizations, Political Conditionality, and Democratic Transformation in Eastern Europe. East European Politics and Societies, 21(1).

WEU. (2000). Western European Union Today, WEU Brussels. Downloaded from: http:// www.weu.int/WEU_Today2.pdf.

Zięba, R. (1999). Instytucjonalizacja bezpieczeństwa europejskiego, Warszawa: Scholar. 